\title{
Kejadian Obesitas, Obesitas Sentral, dan Kelebihan Lemak Viseral pada Lansia Wanita
}

\section{The Incidence of Obesity, Central Obesity, and Excessive Visceral Fat among Elderly Women}

\author{
Ira Maya Sofa*
}

\begin{abstract}
ABSTRAK
Latar Belakang: Obesitas, obesitas sentral, dan lemak viseral merupakan penumpukan lemak tubuh yang berlebihan dan berisiko untuk menimbulkan berbagai penyakit degeneratif seperti jantung iskemi dan stroke serta dapat meningkatkan risiko kerusakan tulang pada lansia.

Tujuan: Tujuan dari penelitian ini adalah untuk menganalisis faktor risiko obesitas, obesitas sentral, dan kelebihan lemak viseral pada lansia wanita.

Metode: Penelitian ini menggunakan desain studi cross sectional dengan pendekatan kuantitatif. Sampel dari penelitian ini adalah 81 lansia wanita yang menjadi anggota posyandu lansia di wilayah kerja Puskesmas Jagir, Wonokromo, Surabaya. Pengumpulan data menggunakan food recall $3 \times 24$ jam, antropometri (berat badan, tinggi badan, dan lingkar perut), lemak viseral menggunakan Bio Impedance Analysis (BIA), serta kuesioner terkait data diri subjek. Data dianalisis dengan menggunakan analisis regresi logistik.

Hasil: Hasil penelitian menujukkan rata-rata usia subjek adalah $67,12 \pm 5,97$. Sebagian besar subjek memiliki riwayat pendidikan rendah $(71,6 \%)$ dan sebanyak $87,7 \%$ subjek tidak bekerja. Rata-rata asupan zat gizi subjek lebih rendah jika dibandingkan dengan Angka Kecukupan Gizi (AKG). Sebanyak $34,6 \%$ subjek mengalami obesitas; angka kejadian obesitas sentral yaitu $17,3 \%$; dan $28,4 \%$ subjek memiliki lemak viseral tubuh berlebih. Uji statistik menunjukkan hubungan signifikan antara usia dengan obesitas ( $p$-value $=0,042$ ), usia dengan obesitas sentral $(p$-value $=0,009$ ) tetapi usia dengan lemak viseral tidak memiliki hubungan signifikan $(p$-value $=0,163)$. Asupan makanan harian, pendidikan, dan pekerjaan tidak menunjukkan hubungan signifikan dengan obesitas, obesitas sentral, maupun lemak viseral ( $p$-value $>0,05)$.

Kesimpulan: Pada lansia, risiko mengalami obesitas maupun obesitas sentral semakin menurun seiring dengan bertambahnya usia. Lemak viseral tidak berhubungan dengan usia.
\end{abstract}

Kata kunci: usia, obesitas, obesitas sentral, lemak viseral, lansia

\section{ABSTRACT}

Background: Obesity, central obesity, and visceral fat is an excessive fat that can release various types of diseases such as cardiovascular disease, stroke and can increase the risk of bone damage in the elderly.

Objectives: The purpose of this study was to analyze the risk factors of obesity, central obesity, and visceral fat in elderly women.

Methods: This was an observational analytic study with cross sectional design. The samples of the study were 81 elderly women registered as member of Posyandu Lansia in the working area of Puskesmas 
Jagir, Wonokromo, Surabaya. The data collected using 3 times 24-hour food recall, anthropometry (body weight, body height, and waist circumference), visceral fat using Bio Impedance Analysis (BIA), and questionnaire related to subject's characteristic. The data were analyzed using logistic regression analysis.

Results: The results showed that the mean age of the subjects were $67.12 \pm 5.97$ years old. Most of the subjects have low education (71.6\%) and $87.7 \%$ of subjects didn't work. The mean value of daily energy intake was $1074.31 \pm 298.67 \mathrm{kcal}$. There were $34.6 \%$ obese subjects, only $17.3 \%$ subjects didn't experience central obesity, and $28.4 \%$ of subjects had excess body visceral fat. The statistical test showed significant correlation between age with obesity ( $p$-value $=0.042)$, age with central obesity ( $p$-value $=0.009$ ) but age with visceral fat had no significant correlation ( $p$-value $=0.163)$. Daily food intake, education, and occupation did not show significant correlation with obesity, central obesity, or visceral fat ( $p$-value $>0.05$ ).

Conclusions: The risk for obesity and central obesity was decreased with aging in elderly but not with visceral fat.

Keywords: age, obesity, central obesity, visceral fat, elderly

\author{
*Koresponden: \\ iramayasofa16@gmail.com \\ Program Studi S1 Gizi, Fakultas Kesehatan Masyarakat, Universitas Airlangga
}

\section{PENDAHULUAN}

Obesitas merupakan suatu keadaan dimana terjadi penumpukan lemak berlebih di dalam tubuh ${ }^{1}$. Obesitas diketahui menjadi salah satu faktor risiko munculnya berbagai penyakit degeneratif seperti penyakit jantung ${ }^{2}$ dan stroke $^{3}$. Penyakit-penyakit tersebut merupakan penyebab kematian terbesar penduduk dunia, terutama pada kelompok usia lanjut ${ }^{4}$. Selain penyakit tersebut, obesitas pada lansia juga dapat meningkatkan risiko terjadinya kerusakan pada tulang dan sendi sehingga dapat meningkatkan risiko terjadinya jatuh atau kecelakaan ${ }^{5}$. Obesitas sentral juga berkaitan erat dengan peningkatan risiko penyakit degeneratif $^{6}$ dimana obesitas sentral ini merupakan penumpukan lemak di perut yang diukur dengan menggunakan indikator lingkar perut ${ }^{7}$. Lemak viseral merupakan lemak tubuh yang terkumpul di bagian sentral tubuh dan melingkupi organ internal. Kelebihan lemak viseral berhubungan erat dengan peningkatan risiko penyakit kardiovaskuler ${ }^{8}$, sindrom metabolik $^{9}$ (hipertensi, dislipidemia, dan diabetes tipe II), dan resistensi insulin ${ }^{10}$. Suatu penelitian menyatakan bahwa seseorang yang mengalami obesitas cenderung memiliki lemak viseral tubuh yang berlebih ${ }^{11}$.

Faktor-faktor yang dapat
mempengaruhi kejadian obesitas di antaranya yaitu tingkat pendidikan dan pekerjaan ${ }^{12}$, asupan makanan ${ }^{13}$, stress $^{14}$, aktivitas fisik ${ }^{13}$, jenis kelamin serta usia ${ }^{15}$. Berdasarkan penelitian analisis lanjutan data Riskesdas 2007 di Jakarta, faktor risiko obesitas sentral di antaranya yaitu usia, jenis kelamin, pendidikan, pekerjaan, pendapatan per kapita, makanan berlemak, dan gangguan mental ${ }^{6}$. Lemak viseral dapat juga mempengaruhi besar lingkar perut sehingga semakin tinggi persen lemak viseral akan semakin meningkatkan risiko mengalami obesitas sentral ${ }^{16}$.

Hasil Riset Kesehatan Dasar (2013) menunjukkan bahwa prevalensi penduduk Indonesia mengalami obesitas sebesar $15,4 \%{ }^{17}$. Prevalensi obesitas pada perempuan dewasa (>18 tahun) mengalami peningkatan sebanyak 18,1\% dari tahun 2007 (13,9\%) menjadi $32,9 \%^{17}$. Surabaya merupakan kota dengan prevalensi penduduk yang mengalami obesitas dan obesitas sentral terbanyak di Jawa Timur yaitu sebesar 27,3\% dan 39,2\% ${ }^{18}$. Penelitian yang dilakukan di Jepang menunjukkan bahwa kelebihan lemak viseral dapat berisiko mengalami resistensi insulin pada lansia ${ }^{19}$. Berdasarkan laporan pemeriksaan kesehatan posyandu lansia di wilayah kerja Puskesmas Jagir tahun 2015, prevalensi penduduk lansia wanita yang mengalami obesitas cukup tinggi yaitu sebanyak $16 \%{ }^{20}$. Oleh karena itu, peneliti 
tertarik untuk menganalisis faktor risiko (usia, riwayat pendidikan, pekerjaan, energi, protein, lemak, karbohidrat, dan serat) kejadian obesitas, obesitas sentral, dan kelebihan lemak viseral pada kelompok wanita lanjut usia di wilayah kerja Puskesmas Jagir, Wonokromo, Surabaya.

\section{METODE}

Penelitian ini dilakukan di wilayah kerja Puskesmas Jagir, Kecamatan Wonokromo, Surabaya pada bulan April hingga Mei 2018. Jenis penelitian ini merupakan penelitian observasional analitik dengan pendekatan kuantitatif dan menggunakan desain penelitian cross sectional. Populasi dari penelitian ini adalah lansia wanita berusia $\geq 60$ tahun $^{21}$ dan menjadi anggota posyandu lansia di wilayah kerja Puskesmas Jagir. Besar sampel dihitung dengan menggunakan rumus uji hipotesis untuk satu proporsi populasi ${ }^{22}$ dengan tingkat kemaknaan 95\% dan kekuatan 90\% sehingga diperoleh jumlah sampel sebanyak 81 orang lansia. Pengambilan sampel dilakukan dengan cara simple random sampling sehingga setiap anggota populasi memiliki kesempatan yang sama untuk dipilih sebagai sampel. Sebelum dilakukan assessment, calon sampel akan diskrining terlebih dahulu untuk mendapatkan sampel yang sesuai dengan kriteria inklusi. Sampel dari penelitian ini adalah lansia wanita yang dapat berkomunikasi dengan baik, tidak bungkuk (dapat berdiri tegak), dan mempunyai ingatan yang baik. Mini Mental State Examination (MMSE) digunakan untuk menilai daya ingat subjek ${ }^{23}$.

Variabel dependen penelitian ini adalah status obesitas, status obesitas sentral, dan status lemak viseral pada lansia wanita. Variabel independen penelitian ini adalah usia, pendidikan, pekerjaan, dan asupan zat gizi harian makanan (energi, protein, lemak, karbohidrat, dan serat). Penelitian ini menggunakan data primer dan data sekunder. Data primer meliputi pengukuran tinggi badan, berat badan, lingkar perut, persen lemak viseral, dan wawancara food recall 24 jam selama 3 hari ( 2 kali pada hari biasa dan 1 kali pada hari libur) serta dilakukan tidak berturutturut untuk menggambarkan rata-rata asupan zat gizinya. Pengukuran tinggi badan menggunakan microtoise merk OneMed dengan tingkat ketelitian $0,1 \mathrm{~cm}$. Pengukuran berat badan dan persen lemak viseral menggunakan alat BIA (Bio Impedance Analysis) dengan merk OMRON HBF-375 yang dibuat di Jepang. Pengukuran lingkar perut menggunakan waist ruler berbahan lentur merk One Med dengan ketelitian 0,1 cm dan posisi pita berada di bagian tengah antara titik tulang rusuk terakhir dan titik ujung lengkung tulang pangkal paha. Subjek dapat memakai pakaian seminimal mungkin dengan bahan yang tidak tebal agar tidak mempengaruhi hasil pengukuran. Hasil dari data food recall 24 jam di-entry ke dalam aplikasi NutriSurvey 2007 dan akan diketahui asupan rata-rata energi, protein, lemak, karbohidrat, dan serat dari responden. Status obesitas diketahui melalui perhitungan indeks massa tubuh (IMT) yaitu dengan membagi berat badan ( $\mathrm{kg}$ ) dengan kuadrat tinggi badan $(\mathrm{m})$. Selanjutnya, data IMT akan dibagi menjadi dua kelompok yaitu yang tidak obesitas (IMT $<27 \mathrm{~kg} / \mathrm{m}^{2}$ ) dan obesitas (IMT $\geq 27 \mathrm{~kg} / \mathrm{m}^{2}$ ). Subjek yang memiliki lingkar perut $\leq 80 \mathrm{~cm}$ termasuk dalam kelompok tidak obesitas sentral dan $>80 \mathrm{~cm}$ termasuk dalam obesitas sentral. Cut off point dari lemak viseral yang normal menggunakan standar dari OMRON yaitu 0,5 \% - 9,5\% sehingga lebih dari itu dikatakan kelebihan lemak viseral ${ }^{24}$. Data sekunder meliputi data jumlah lansia wanita yang menjadi anggota posyandu lansia di wilayah kerja Puskesmas Jagir.

Penelitian telah mendapatkan persetujuan komisi etik Fakultas Kesehatan Masyarakat Universias Airlangga dengan nomor 201-KEPK tanggal 27 April 2018. Setiap responden telah menyetujui ikut serta dalam penelitian ini melalui informed consent.

\section{HASIL DAN PEMBAHASAN}

Penelitian ini dilakukan pada 81 subjek lansia wanita dengan rentang usia 60 sampai 85 tahun. Rata-rata usia subjek adalah $67,12 \pm 5,97$ tahun. Sebagian besar subjek memiliki riwayat pendidikan rendah $(71,6 \%)$ yaitu subjek yang tidak pernah sekolah hingga tamat SMP. Sebanyak 71 subjek $(87,7 \%)$ tidak bekerja dan hanya 8 subjek $(9,9 \%)$ yang memiliki pekerjaan tidak tetap seperti 
Tabel 1. Karakteristik Lansia Wanita di wilayah Kerja Puskesmas Jagir, Wonorkomo, Surabaya

\begin{tabular}{|c|c|c|c|c|c|c|}
\hline \multirow{2}{*}{$\begin{array}{l}\text { Variabel } \\
\text { Usia (tahun) }\end{array}$} & & \multicolumn{3}{|c|}{$\begin{array}{l}\text { Total } \\
\mathrm{n}=\mathbf{8 1}\end{array}$} & \multirow{2}{*}{$\begin{array}{c}\text { Minimum } \\
60,00\end{array}$} & \multirow{2}{*}{$\begin{array}{c}\text { Maksimum } \\
85,00\end{array}$} \\
\hline & & 67,12 & \pm & 5,97 & & \\
\hline \multicolumn{2}{|c|}{ Tinggi Badan (cm) } & 149,59 & \pm & 7,04 & 135,00 & 182,00 \\
\hline \multicolumn{2}{|l|}{ Berat Badan (kg) } & 57,20 & \pm & 11,76 & 30,50 & 87,00 \\
\hline \multicolumn{2}{|c|}{ Indeks Massa Tubuh $\left(\mathrm{kg} / \mathrm{m}^{2}\right)$} & 25,47 & \pm & 4,48 & 15,56 & 35,59 \\
\hline \multicolumn{2}{|c|}{ Lingkar Perut (cm) } & 88,83 & \pm & 10,22 & 63,00 & 112,00 \\
\hline \multicolumn{2}{|c|}{ Lemak Viseral (\%) } & 9,84 & \pm & 5,11 & 1,00 & 21,50 \\
\hline \multirow[t]{5}{*}{ Asupan Harian } & Energi (kkal) & 1074,31 & \pm & 298,67 & 412,6 & 1903,43 \\
\hline & Protein (g) & 38,34 & \pm & 13,69 & 14,17 & 74,7 \\
\hline & Lemak (g) & 44,84 & \pm & 17,50 & 5,70 & 115,87 \\
\hline & Karbohidrat (g) & 136,91 & \pm & 51,58 & 60,87 & 384,03 \\
\hline & Serat (g) & 8,17 & \pm & 5,30 & 1,70 & 39,83 \\
\hline
\end{tabular}

Tabel 2. Hubungan antara Variabel Independen dengan Variabel Dependen

\begin{tabular}{llccc}
\hline \multicolumn{2}{l}{ Variabel } & Status Obesitas & Status Obesitas Sentral & Status Lemak Viseral \\
\cline { 3 - 5 } \multicolumn{1}{l}{ Usia } & & $\boldsymbol{p}$-value & $\boldsymbol{p}$-value & $\boldsymbol{p}$-value \\
Asupan Zat Gizi & $0,042^{*}$ & $0,009^{*}$ & $0,178^{*}$ \\
& & 0,693 & 0,854 & 0,608 \\
& Energi & 0,767 & 0,647 & 0,281 \\
& Protein & 0,718 & 0,662 & 0,318 \\
& Lemak & 0,610 & 0,401 & 0,670 \\
& Karbohidrat & 0,615 & 0,802 \\
& Serat & 0,876 & 0,615 & 0,718 \\
& Rendah & 0,826 & 0,708 & 0,942 \\
& Sedang & 0,957 & 0,631 & 0,772 \\
\hline
\end{tabular}

Keterangan: $\quad$ Tanda * menunjukkan hubungan yang signifikan yaitu $p<\alpha ; \alpha=0,05$; data dianalisis dengan menggunakan Uji Regresi Logistik

wiraswasta, petani, nelayan, atau buruh. Ratarata indeks masa tubuh (IMT) responden yaitu sebesar $25,47 \pm 4,48 \mathrm{~kg} / \mathrm{m}^{2}$ dan termasuk ke dalam kategori berat badan lebih. Penelitian yang dilakukan di Brazil terkait peningkatan berat pada lansia wanita, rata-rata IMT subjek yaitu $25,6 \mathrm{~kg} / \mathrm{m}^{225}$. Rata-rata subjek penelitian ini mengalami obesitas sentral jika dibandingkan dengan standar lingkar perut perempuan normal. Persentase lemak viseral tubuh dari subjek penelitian rata-rata masih tergolong normal yaitu kurang dari sama dengan 9,5 persen. Untuk rata-rata asupan harian, asupan energi, protein, karbohidrat, dan serat lebih rendah $(<80 \%)^{26}$ dibandingkan dengan Angka Kecukupan Gizi untuk lansia wanita (65 - 80 tahun) yaitu energi 1550 kkal; protein 56 gram; lemak 43 gram; karbohidrat
252 gram; dan serat 22 gram. Hal ini kemungkinan disebabkan oleh penurunan nafsu makan yang dialami oleh lansia karena perubahan fisiologis seperti perubahan sistem pencernaan dan hormonal atau dapat juga disebabkan karena penyakit yang diderita ${ }^{27}$. Asupan lemak dari subjek penelitian ini ratarata sudah mencukupi kebutuhan berdasarkan AKG yaitu 104,28\% kebutuhan lemak (44,84 gram). Lansia lebih cenderung menyukai makanan berlemak karena memiliki rasa yang lebih enak sehingga asupan lemaknya lebih banyak jika dibandingkan dengan zat gizi lain ${ }^{28}$.

Prevalensi lansia wanita yang mengalami obesitas pada penelitian ini adalah sebanyak $34,6 \%$. Pada penelitian yang dilakukan di Korea ditemukan 37,8\% lansia mengalami obesitas ${ }^{28}$. Sebagian besar subjek 
mengalami obesitas sentral dan hanya $17,3 \%$ yang memiliki lingkar perut normal. Penelitian yang dilakukan pada komunitas Ahmedabad, India juga menunjukkan prevalensi obesitas sentral yang lebih dari $50 \%$ pada jenis kelamin wanita $^{29}$. Namun, penelitian yang dilakukan di Padang menemukan sebanyak $46,5 \%$ lansia wanita mengalami obesitas sentral ${ }^{30}$. Sebanyak $28,4 \%$ subjek memiliki persentase lemak viseral tubuh yang berlebih. Kelebihan lemak viseral pada lansia dapat meningkatkan risiko untuk terjadinya resistensi insulin ${ }^{19}$.
Pada Tabel 2 dapat dilihat hubungan antara usia, asupan harian, pendidikan, dan pekerjaan (variabel independen) dengan obesitas, obesitas sentral, dan kelebihan lemak viseral (variabel dependen). Dari tabel tersebut, dapat diketahui bahwa asupan harian, pendidikan, dan pekerjaan tidak menujukkan hubungan yang signifikan terhadap obesitas, obesitas sentral, maupun kelebihan lemak viseral ( $p$-value $>0,05)$. Tetapi, pada penelitian ini hanya usia yang memiliki hubungan signifikan dengan obesitas dan obesitas sentral ( $p$-value $<0,05)$.

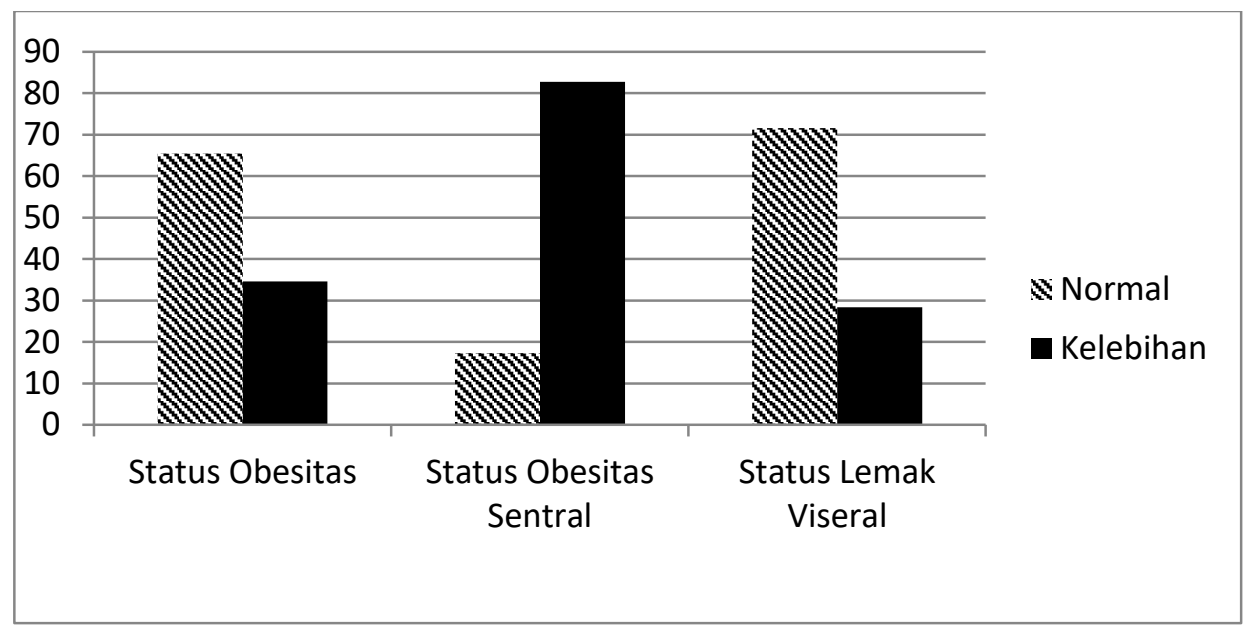

Gambar 1. Persentase Status Obesitas, Status Obesitas Sentral, dan Status Lemak Viseral

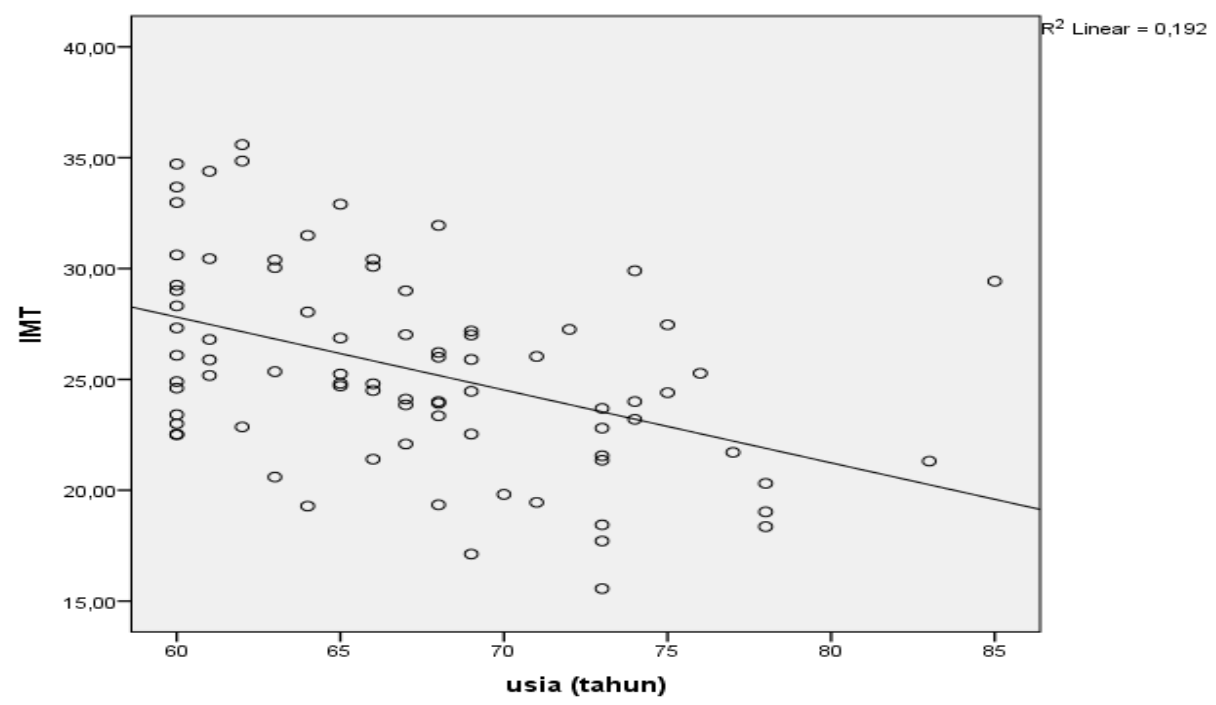

Gambar 2. Hubungan antara Usia dengan Indeks Masa Tubuh (IMT) 


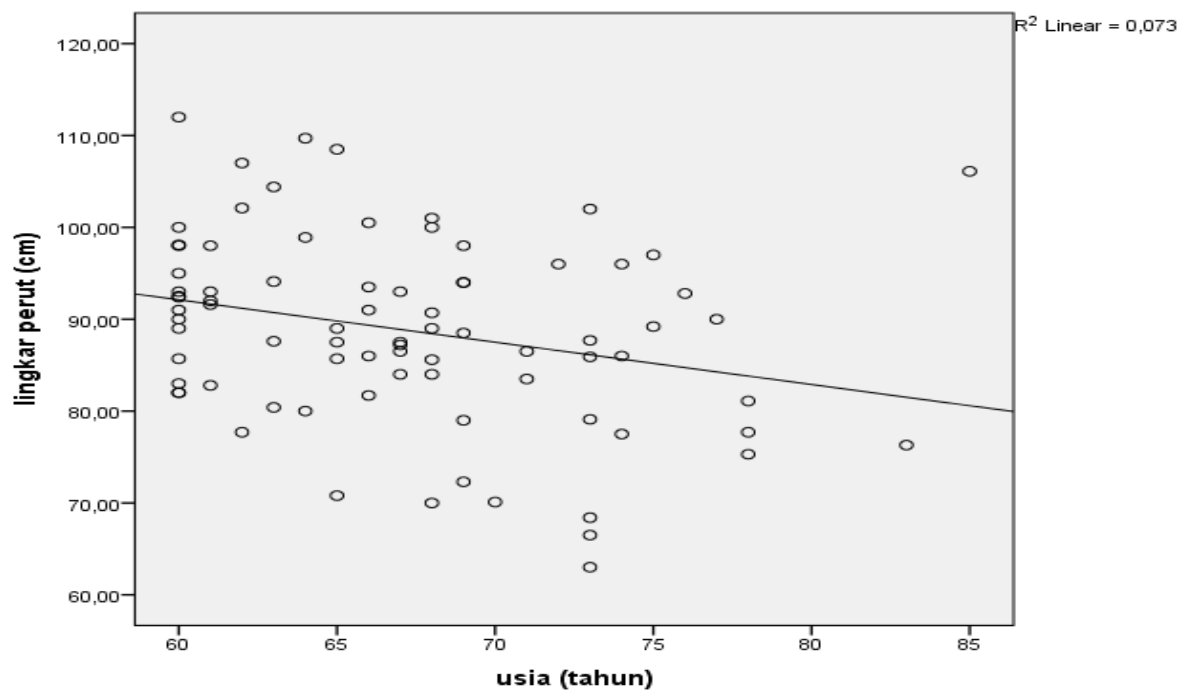

Gambar 3. Hubungan antara Usia dengan Lingkar Perut

Usia berhubungan memiliki hubungan signifikan dengan status obesitas (OR $=0,904$; $95 \% \mathrm{Cl}=0,821-0,996 ; \mathrm{P}=0,042)$ dan status obesitas sentral (OR $=0,839 ; 95 \% \mathrm{Cl}=0,735-$ 0,957; $P=0,009)$. Pada Gambar 2 dan Gambar 3 menunjukkan hubungan antara usia dengan Indeks Masa Tubuh (IMT) serta lingkar perut. Semakin bertambahnya usia maka IMT akan semakin menurun sehingga kejadian obesitas juga semakin menurun. Hal ini didukung dengan penelitian yang dilakukan pada lansia terkait faktor obesitas bahwa seiring dengan bertambahnya usia prevalensi obesitas semakin menurun ${ }^{31}$.

Selain itu, penelitian yang dilakukan di Jakarta juga mengemukakan bahwa usia memiliki hubungan yang signifikan dengan kejadian obesitas sentral ${ }^{6}$. Obesitas dan obesitas sentral pada lansia dapat disebabkan karena rendahnya aktivitas fisik dan perubahan hormonal sehingga dapat terjadi penumpukan lemak dalam tubuh ${ }^{32}$. Namun ketika memasuki usia lanjut, terjadi perubahan komposisi tubuh seiring dengan penuaan dimana massa tubuh tanpa lemak (lean body mass) menurun sehingga berat badan mengalami penurunan tetapi terjadi peningkatan lemak tubuh ${ }^{33,34}$.

Lingkar perut juga semakin menurun seiring dengan bertambahnya usia sehingga kejadian obesitas sentral semakin menurun ${ }^{35}$. Penurunan berat badan yang berkibat pada menurunnya IMT dan lingkar perut pada saat penuaan ini juga terjadi karena faktor psikososial (depresi dan demensia) yang dapat mengakibatkan penurunan nafsu makan dan penurunan motivasi untuk membeli dan menyiapkan makanan ${ }^{33}$ serta faktor penyakit yang diderita seperti penyakit pada ginjal, saluran pencernaan, ataupun penyakit pernafasan ${ }^{36}$. Penurunan metabolisme basal juga dapat mempengaruhi penurunan berat badan pada masa penuaan karena lansia merasa kenyang lebih lama sehingga asupan makanannya lebih sedikit ${ }^{33}$. Selain itu, lansia wanita cenderung mengalami penurunan nafsu makan sehingga asupan zat gizi ke dalam tubuh juga menurun ${ }^{27}$. Meskipun kecenderungan obesitas dan obesitas sentral semakin menurun seiring bertambahnya usia, status gizi tetap harus diperhatikan dan ditingkatkan agar lansia dapat terhindar dari berbagai risiko penyakit degeneratif dan kualitas hidup semakin meningkat.

Dalam penelitian ini ditemukan bahwa asupan zat gizi (energi, protein, lemak, karbohidrat, dan serat) tidak memiliki hubungan yang signifkan dengan kejadian obesitas maupun obesitas sentral ( $p$-value > $0,05)$. Pada penelitian dengan desian studi case control menunjukkan hal yang berbeda yaitu terdapat perbedaan yang siginifikan antara asupan energi, protein, lemak, dan karbohidrat pada subjek wanita yang tidak mengalami obesitas sentral dan yang mengalami obesitas sentral ${ }^{37}$. Kejadian obesitas sentral pada penelitian ini dapat dikarenakan faktor lain yang tidak diteliti seperti aktivitas fisik. Penelitian yang dilakukan pada lansia di Inggris menunjukkan bahwa subjek yang melakukan aktivitas fisik lebih sedikit cenderung memiliki 
IMT yang lebih tinggi ${ }^{38}$. Riwayat pendidikan tidak memiliki hubungan yang signifikan dengan obesitas dan obesitas sentral. Penelitian yang dilakukan pada subjek yang memiliki riwayat pendidikan rendah (tidak sekolah hingga SMP) juga menunjukkan hal yang sama dengan penelitian ini dimana pendidikan dengan obesitas sentral tidak memiliki hubungan yang signifikan ( $p$-value $=$ $0,087)^{6}$. Hubungan yang tidak signifikan antara riwayat pendidikan dengan obesitas maupun obesitas sentral ini dapat dikarenakan sebagian besar subjek memiliki riwayat pendidikan yang rendah $(71,6 \%)$. Selain itu, faktor yang lebih berhubungan dengan kejadian obesitas yaitu dapat dikarenakan konsumsi makanan yang tidak sehat dan aktivitas fisik ${ }^{39}$. Pekerjaan yang dilakukan oleh subjek juga tidak memiliki hubungan yang signifikan dengan obesitas dan obesitas sentral dikarenakan sebagian besar subjek sudah tidak bekerja.

Lemak viseral dalam penelitian ini tidak memiliki hubungan yang signifikan dengan variabel independen (usia, asupan makanan harian, pendidikan, dan pekerjaan). Berbagai penelitian menemukan bahwa lemak viseral memiliki hubungan yang signifikan dengan asupan zat gizi ${ }^{40}$ dan usia $^{34}$. Suatu penelitian terkait komposisi lemak tubuh menunjukkan hasil bahwa semakin bertambahnya usia, persen lemak tubuh juga semakin meningkat ${ }^{34}$. Berbagai penelitian tersebut menunjukkan hal yang berbeda dengan hasil penelitian yang dilakukan pada lansia wanita ini. Hal ini kemungkinan disebabkan karena rata-rata persen lemak viseral tubuh subjek penelitian ini masih tergolong normal. Aktivitas fisik dapat membantu mengoptimalkan persen lemak viseral tubuh ${ }^{41}$, namun dalam penelitian ini aktivitas fisik tidak diidentifikasi sehingga menjadi keterbatasan dalam menganalisis hubungannya dengan lemak viseral dan variabel dependen lain.

Penelitian ini menggunakan food recall 24 jam sebanyak 3 kali secara tidak berurutan (2 kali dilakukan penilaian pada hari biasa dan 1 kali penilaian dilakukan pada hari libur) sehingga dapat menggambarkan tingkat asupan lansia wanita yang ada di wilayah kerja Puskesmas Jagir. Keterbatasan dari penelitian ini adalah aktivitas fisik dari respon den tidak diukur sebagai salah satu variabel independen.

\section{KESIMPULAN}

Asupan zat tidak gizi, pendidikan, dan pekerjaan tidak memiliki hubungan yang signifikan dengan obesitas, obesitas sentral, maupun lemak viseral. Pada lansia, usia memiliki hubungan yang signifikan dengan obesitas dan obesitas sentral dimana semakin bertambahnya usia, makan kecenderungan untuk mengalami obesitas dan obesitas sentral semakin menurun. Usia tidak memiliki hubungan yang signifikan dengan lemak viseral.

\section{ACKNOWLEDGEMENT}

Terima kasih penulis berikan kepada Bakesbangpol Kota Surabaya, Dinkes Kota Surabaya, Puskesmas Jagir Wonokromo Surabaya, dan para kader posyandu lansia yang telah membantu dalam pelaksanaan pengambilan data.

\section{REFERENSI}

1. 2009 ICD-9-CM Diagnosis Codes 278.* : Overweight, obesity and other hyperalimentation. Tersedia pada: www.icd9data.com/2009/Volume1/240 -279/270-279/278/default.htm.

(Diakses: 22 Juni 2018)

2. Thomsen, M. \& Nordestgaard, B. G. Myocardial Infarction and Ischemic Heart Disease in Overweight and Obesity With and Without Metabolic Syndrome. J. Am. Med. Assoc. 174, 15-22 (2015).

3. Haley, M. J. \& Lawrence, C. B. Obesity and stroke: Can we translate from rodents to patients? (2016). doi:10.1177/0271678X16670411

4. WHO. WHO | Projections of mortality and causes of death, 2015 and 2030. WHO (2017).

5. Rontoyanni, V. G., Avila, J. C., Kaul, S., Wong, R. \& Veeranki, S. P. Association between obesity and serum 25(OH)D concentrations in older Mexican adults. Nutrients 9, 1-12 (2017).

6. Sugianti, E., Hardinsyah \& Afriansyah, N. Faktor Risiko Obesitas Sentral pada Orang Dewasa dI DKI Jakarta: Analisis Lanjut Data RISKESDAS 2007. Gizi Indon 
32, 105-116 (2009).

7. WHO. Waist Circumference and WaistHip Ratio: Report of a WHO Expert Consultation. World Heal. Organ. 8-11 (2008). doi:10.1038/ejcn.2009.139

8. Després, J. P., Arsenault, B. J., Côté, M., Cartier, A. \& Lemieux, I. Abdominal obesity: The cholesterol of the 21st century? Can. J. Cardiol. 24, 7-12 (2008).

9. Tatsumi, Y. et al. Risk for metabolic diseases in normal weight individuals with visceral fat accumulation: A crosssectional study in Japan. BMJ Open 7, 18 (2017).

10. Sandeep, S., Gokulakrishnan, K., Velmurugan, K., Deepa, M. \& Mohan, V. Visceral \& subcutaneous abdominal fat in relation to insulin resistance \& metabolic syndrome in non-diabetic south Indians. Indian J. Med. Res. 131, 629-635 (2010).

11. Bertin, B., Desreumaux, P. \& Dubuquoy, L. Obesity, visceral fat and Crohn' s disease. (2010). doi:10.1097/MCO.0b013e32833cf0f4

12. Sartorius, B. et al. Carbohydrate intake, obesity, metabolic syndrome and cancer risk? A two-part systematic review and meta-analysis protocol to estimate attributability. BMJ Open 6, (2016).

13. Rodríguez Martín, A., Ruiz, J. P. N., Nieto, J. M. M. \& Jiménez, L. E. Life-style factors associated with overweight and obesity among Spanish adults. Nutr. Hosp. 24, 144-151 (2009).

14. Sinha, R. \& Jastreboff, A. M. Stress as a common risk factor for obesity and addiction. Biol. Psychiatry 73, 827-835 (2013).

15. Sen, J., Mondal, N. \& Dutta, S. Factors affecting overweight and obesity among urban adults: A cross-sectional study. Epidemiol. Biostat. Public Heal. 10, 1-11 (2013).

16. Gadekar, T., Dudeja, P., Basu, I., Vashisht, S. \& Mukherji, S. Correlation of visceral body fat with waist-hip ratio, waist circumference and body mass index in healthy adults: A cross sectional study. Med. J. Armed Forces India 1-6 (2018). doi:10.1016/j.mjafi.2017.12.001

17. Kemenkes RI. Riset Kesehatan Dasar
(RISKESDAS) 2013. Lap. Nas. 2013 1-384 (2013). doi:1 Desember 2013

18. Kemenkes RI. Riset Kesehatan Dasar 2013 Dalam Angka Provinsi Jawa Timur. (2013).

19. Umegaki, H., Haimoto, H., Ishikawa, J. \& Kario, K. Visceral Fat Contribution of Insulin Resistance in Elderly People. J. Am. Geriatr. Soc. 56, 1373-1375 (2008).

20. Puskesmas Jagir. Laporan Pemeriksaan Laboratorium pada Lansia di Posyandu Lansia Puskesmas Jagir Tahun 2015. (2015).

21. Kemenkes RI. PMK No.25 Tentang Rencana Aksi Nasional Lanjut Usia Tahun 2016-2019. 96 (2016).

22. Lemeshow, S., Hosmer Jr, D. W., Klar, J. \& Lwanga, S. K. Part 1: Statistical Methods for Sample Size Determination. Adequacy Sample Size Heal. Stud. 247 (1990). doi:10.1186/1472-6963-14-335

23. Vertesi, a et al. Standardized MiniMental State Examination. Use and interpretation. Can. Fam. Physician 47, 2018-23 (2001).

24. Omron Healthcare Co Ltd. Body Composition Monitor HBF-375 Instruction Manual.

25. Corona, L. P. et al. Weight Gain Among Elderly Women as Risk Factor for Disability : Health, Well-Being and Aging Study ( SABE Study ). J. Aging Health 25, 119-135 (2013).

26. Widyakarya Nasional Pangan dan Gizi (WNPG). Pemantapan Ketahanan Pangan dan Perbaikan Gizi Berbasis Kemandirian dan Kearifan Lokal. (Lembaga IImu Pengetahuan Indonesia, 2012).

27. Pilgrim, A. \& Robinson, S. An overview of appetite decline in older people. Nurs Older People 27, 29-35 (2015).

28. Kwon, Y. N., Yoon, S. S., Lee, K. \& Lee, K. Sarcopenic Obesity in Elderly Korean Women: A Nationwide Cross-sectional Study. 53-58 (2018).

29. Vyas, N. J., Chaudhary, M. I. \& Sheth, M. S. Prevalence of obesity and central obesity in middle aged population of Ahmedabad. (2017). doi:10.5455/jcer.

30. Kamso, S. Dislipidemia dan Obesitas Sentral pada Lanjut Usia di Kota Padang. 
J. Kesehat. Masy. Nas. 2, Nomor 2, 7377 (2007).

31. Shebl, A. M., Hatata, E. S. Z., Boughdady, A. M. \& El-Sayed, S. M. Prevalence and Risk Factors of Obesity among Elderly Attending Geriatric Outpatient Clinics in Mansoura City. J. Educ. Pract. 6, 136-147 (2015).

32. Newman, A. M. American Nurses Association - Obesity in Older Adults Page 1 of 8 Obesity in Older Adults American Nurses Association - Obesity in Older Adults Page 2 of 8 . OJIN Online J. Issues Nurs. 14, 1-8 (2009).

33. Gaddey, H. L. \& Holder, K. Unintentional weight loss in older adults. Am. Fam. Physician 89, 718-722 (2014).

34. St-Onge, M. P. \& Gallagher, D. Body composition changes with aging: The cause or the result of alterations in metabolic rate and macronutrient oxidation? Nutrition 26, 152-155 (2010).

35. Flegal, K. M. et al. Comparisons of percentage body fat, body mass index, waist circumference, and waist-stature ratio in adults $1-3$. Am. J. Clin. Nutr. 89, 500-508 (2009).

36. Metalidis, C., Knockaert, D. C., Bobbaers, H. \& Vanderschueren, S. Involuntary weight loss. Does a negative baseline evaluation provide adequate reassurance? Eur. J. Intern. Med. 19, 345-349 (2008).

37. Rahmandita, A. P. \& Adriani, M. Perbedaan Tingkat Konsumsi dan Aktivitas Fisik pada Wanita (20-54 Tahun) Obesitas Sentral dan Non Sentral. Amerta Nutr. 1, 266-274 (2017).

38. Bradbury, K. E., Guo, W., Cairns, B. J., Armstrong, M. E. G. \& Key, T. J. Association between physical activity and body fat percentage, with adjustment for BMI: a large crosssectional analysis of UK Biobank. BMJ Open 7, e011843 (2017).

39. Shankar, A., Sabanayagam, C., Saw, S. M., Tai, E. S. \& Wong, T. Y. The association between socioeconomic status and overweight/obesity in a malay population in Singapore. AsiaPacific J. Public Heal. 21, 487-496 (2009).

40. Guyenet, S. J. \& Schwartz, M. W. Regulation of food intake, energy balance, and body fat mass: Implications for the pathogenesis and treatment of obesity. J. Clin. Endocrinol. Metab. 97, 745-755 (2012).

41. Irving, B. a et al. Body Composition. Med Sci Sport. 40, 1863-1872 (2009). 